World Bank Reprint Series: Number Seventy-three

Surjit S. Bhalla

\title{
The Role of Sources of Income and Investment Opportunities in Rural Savings
}

Reprinted from Journal of Development Economics 5 (1978) 


\title{
THE ROLE OF SOURCES OF INCOME AND INVESTMENT OPPORTUNITIES IN RURAL SAVINGS
}

\author{
Surjit S. BHALLA* \\ The World Bank, Washington, DC 20433, U.S.A.
}

Received I uly 1977, revised version received December 1977

\begin{abstract}
This paper investigates the effect that sources of income and investment opportunitics have on the savings behavior of farm households in rural India. The panel nature of the data (agricultural years 1968-69, 1969-70 and 1970-71) allows for the identification of the permanent and transitory componer is of a household's income. It is shown that income variability (rather than investment opportunities) can account for observed differences in the propensity to save out of different sources (agricultural/non-agricultural). A direct test of the effect of investment opportunities ne savings is offered ir! the second part of the paper. It is observed that capital market conditions have an important effect on this relationship; poor households save more, and rich households save less, in response to an increase in investment opportunities.
\end{abstract}

\section{Introduction}

The traditional view that low incomes in rural areas of developing countries preclude the generation of savings has been challenged by the contention that low rates of return to investment result in low savings. This 'new' view ${ }^{1}$ implicitly assumes that aggregate houschold sivings respond positively to increases in rates of return to investments (savings). The assumption is important because of its implication for development stra. tegies; in particular, it suggests that the setting up of financial intermediaries, and a 'realistic' interest rate policy, will not only lead to an improvement in the capital market, but also to an increase in rural savings, capital formation and growth.

The absence of detailed data on financial intermediaries impairs the testing of any relationship between interest rates and rural savings. However, farm households (a major proportion of 'saver' households) receive a return on

* An earlier version of this paper formed part of a report written for the World Bink, Aspects of savings behavior in rural India. I am grilteful to the institution for its finimcial support. I would like to thank Suman K. Bery, Robert Z. Lawrence and Philip Musgrove for helpful discussions, and anonymous referees for comments on an earlier draft. The views cxpressed in this paper are mine alone.

${ }^{1}$ See Schultz (1964) for a detailed discussion of this view. Also see McKinnon (1973) and Adams (1973). 
the1r saviags through on-farm investments. Evidence on household responses to differences in these rates of return (investment opportunities) can be used, therefore, to generalize to a statement on the yield sensitivity of savings, e.g. if sivings are inelastic with respect to rates of return on investments, then interest rate policy will not have a substantial effect on household savings.

Differences in investment opportunities, however, are difficult to measure: consequently, a direct test of their effect on household savings has (apparently) never been conducted. A popular form of an indirect test is to divide income into its sources-profits and wages for aggregate data, and agricultural/non-agricultural income for rural household data. ${ }^{2}$ Observed differences in the propensities to save from the respective sources are then ascribed (partly) to differences in investment opportunities.

Section 2 offers a critical assessment of these studies. It is argued that the emphasis on investment opportunities as an explanator of savings may be misplaced. An alternative explanation, [Friedman (1957)]-namely, that propinsities to save reflect the variability of insome streams - is offered and empirically tested. The basis for these tests is the data collected by the Vational Council of Applied Economic Research (NCAER) on 1980 farm (cultivator) households in rural India for three years -1968. 69 to 1970-71. This data has detailed information on the production, consumption, savings, and suurces of income for these households. ${ }^{3}$

Section 3 is concerned with a direct test of the hypothesis relating imestment oprortunities and farm household savings. The theoretical basis of the hypothesis is examined, and it is shown that assumptions about the nature of the capital market crucially affect the conclusions regarding farm household savings: in particular, a perfect market for funds will imply a decline in household savings with an increase in investment opportunities. The attributes of a proper measure for investment opportunities are discussed, and the longitudinal nature of the data exploited to construct such an index. The section concludes with an empirical test which conforms fircrably with theoretical predictions. Section 4 summarizes the conclusions of this paper.

\section{Sources of income and savings}

The propensity to save out of different sources of income has received considerable attention in both the growth theory and economic development literature. Identification of the source of income (profits, wages, agricultural income, non-agricultural income, etc.) is not relevant per st for a study of silvings hehavior. A rupee is a rupee and presumably the houschold does not

\footnotetext{
${ }^{2} \mathrm{~A}$ partial listing of these studies includes Kaldor (1955), Houthakker (1965), Kelley Williamson (1968), Shinohara (1970), Ong Adenns Singh (1976).

${ }^{3}$ See appendix 1 for a brief description of the data. Also see NCAER (1974).
} 
determine its behavior on the basis of the source of income. Rather, its importance is derived rom the assumption that such a classification allows one to stratify households according to differences in the economic environment. Thus, sources of income become a proxy for economic unobservables, and conclusions about the effect of the latter can be drawn from observations on the former.

As mentioned previously, one particular economic unobservable for which sources of income can act as a proxy is investment opportunities. A traditional method of analysis is to divide income on the basis of occupation into two sources-profits (entrepreneurs) and wages (workers). The higher observed propensity to save out of profits is then interpreted as supporting the notion that savings are interest elastic-this under the assumption that capitalists systematically face higher rates of return on their investments, and therefore save more. ${ }^{4}$

However, alternative explanations are possible. Profits and mirginal saving rates may be positively correlated with levels of permanent income; ${ }^{5}$ hence, the higher observed propensity to save out of profits. Further, differences in the variability of the (profits and wages) income streams may cause differences in the observed propensities. If it is assumed that entrepreneurial income is inherently more variable than salary income, then at any given level of income, transitory income will form a larger part of total income for the self-employed. Thus, any cross-section data will show a higher saving rate for the intrepreneur. ${ }^{6}$

The above explanations for the higher propensity to save on the part of the capitalists are not mutually exclusive. Thus, there is no way to choose between the different explanations - is it the higher level of permanent inicome, or the greater variability, or profitable outlets for siving or just tastes that cause entrepreneurs to save at a higher rate?

The longitudinal nature of the NCAER data allows one to be more precise about the different causes of savings. In particular, a relatively rigorous test of Friedman's contention, that it is the variability in income which accounts

\footnotetext{
${ }^{4}$ The assumption that capitalists face higher rates of return on their investments is plausible. Real rates of interest on financial savings are low, if not negative, in most developing countries. See McKinnon (1973) for an elaboration on this point.

${ }^{5}$ Both the permanent income hypotnesis (PIH) of Friedman (1957), and the life cycle hypothesis (LCH) of Ando Modigliani-Brumberg assert that saving rates are imlependint of the level of permanent lifetime income. This 'independence proposition' has proved to be controversial and a summary of the conflicting evidence is provided by Mayer (1972). It should be noted that not a single study for a developing country supports the independence propusition. See Bhalla (1976a, 1976b) and Musgrove (1974) for a refutation of the proposition for India and Colombia, respectively. In these studies, saving rates are shown to increase with the level of permanent income.

${ }^{6}$ This requires the issumption that the marginal propensily to save (MPS) out of transitory income is greater than the MPS out of permanent income - an assumption supported by most analyses of savings behavior.
} 
for higher observed propensities, is conducted in the latter half of this section. But first a 'traditional' analysis of savings and sources of income is presented.

\subsection{Re'se'urch with farm data}

The easy distinction between a capitalist and a worker is lost when one altempts to study the sources of income hypothesis for farmers. The income from a farm is a return to both labor and capital, and cannot be easily separated into its components. Farm incomes can, however, be divided into their on-farm and off-farm components, and thus a division of income into separate sources can be achieved. This differentiation is comparable to the traditional capitalist,worker dichotomy since a major component of off-farm income is labor income. Thus, it can be asserted that a household which derives all of its income from a farm systematically differs from one which derives only 50 perrent of its income in a like manner. The former is likely to have greater control over physical assets, a higher ratio of profit;income and (perhaps) greater investment opportunities.

This sources of income hypothesis has been tested by Kelly. Williamson (1968) for Indonesia and by Ong et al. (1976) for Taiwan. ${ }^{7}$ The empirical methodology of these studies consists essentially of first grouping households by their share of agricultural income in total income, and then estimating the following equation for each group: ${ }^{8}$

$$
S=a+b\left(Y_{a}+Y_{o}\right)
$$

where $S, Y_{a}$ and $Y_{o}$ represent savings, agricultural income and nonagricultural income, per capita, respectively. (For a complete definition of these variables, see appendix 2 .)

In both studies, the average and marginal saving rates are found to increase with the share of agricultural income. This result is then interpreted by the authors as supporting the theory that entrepreneurs, or farms with grealter control over assets, save more; alternatively, the higher savings rate is presumed to reflect the higher investment opportunities of the full time farmer.

Given the capitalist' ${ }^{\prime}$ worker (or profits/wages) dichotomy, this result is not surpising, a priori. However, there are two problems associated with the methodology of these studies. Firstly, estimating an equation like (1) forces

"Other studies of this kind include the following for Japan: Mizoguchi (1970), Noda (1970), and Shinohara (1970).

${ }^{8}$ Kelly Williamson emplıy a slightly different estimation procedure i.e. they estimate equations which reflect the cumulative proportions of income that are derived from agriculture -11 percent, 21 percent....... 91 percent. 
the propensities to save to be the same within each group; thus, it is impossible to test whether propensities to save differ by source of income. Secondly, an increasing ratio of agricultural income/total income may be positively correlated with increasing total income. (The simple correlation between the two is 0.24 in the NCAER data.) If savings rates are associated with the level of income, then what one observes by running regressions of ratio groups is simply the effect of higher incomes rather than the effect of 'control over assets', 'entrepreneurial income' or 'investment opportunities'.

A 'proper' tesî of differences in propensities to save income is to estimate an equation like

$$
S=a+b_{a} Y_{a}+b_{o} Y_{o}
$$

for each homogeneous group of households. Differences in $b_{a}$ and $b_{o}$ can then be interpreted as indicative of differing propensities to save.

The NCAER data for the 1970-71 agricultural year was used to estimate eqs. (1) and (2) for 1980 farm households. In order to duplicate earlier research efforts, the sample was divided into six groups houscholds grouped by the share of agricultural income in total income, $S_{a g}(<50$ percent, 51) 75 percent and $>75$ percent), and land owning categories ( $<5$ acres, 515 acres, and $>15$ acres) ${ }^{9}$

The results for eqs. (1) and (2) (and associated data) are presented in table 1. As also observed by Kelly-Williamson and Ong et al., the orerull propensity to save income does increase with the share of agricultural income and land ownership. However, as the table makes clear, the size of income also increases and therefore attribution of differences in the marginal propensity to save (MPS) to sources of income is questionathle.

Pegarding eq. (2), it is seen that except for one group $\left(S_{a g}=50.75^{\circ}{ }_{0}\right)$, the $M P S$ out of non-agricultural income, $b_{a}$, is always higher than the MPS out of agricultural income, $b_{a}$. The two coefficients are significantiy different for the following groups-all households, $S_{a g}>75 \%$, and land categories $<5$ acres and 5-15 acres. For the exception group, $S_{a g}=50-75 \%, b_{0}$ is less than $b_{a}$, but the difference is not significant at the 10 percent level of confidence.

These results are contrary to expectations. If it is assumed that $Y_{a}$ roughly corresponds to profits and $Y_{o}$ to wages, then one should have observed that $b_{a}$ was greater than $b_{o}$. Analogously, the size of $Y_{a}$ could be a proxy for investment opportunities - again, prior belief would indicalc that $b_{a}>b_{0}$.

Though contrary to other hypotheses, the result that $b_{o}>b_{a}$ is entirely consistent with the interpretation that sources of income mercly reflect the

\footnotetext{
${ }^{9}$ The classifications were chosen to create homogeneous groups - it is implicily assumed that the size of farm owned and/or the share of agricultural income are indicative of asset holdings, ratio of profits to wages, investment opportunities, etc.
} 
Table 1

Sources of income and savings - cultivators, 1970-71.

\begin{tabular}{|c|c|c|c|c|c|c|c|c|}
\hline & \multicolumn{3}{|c|}{ Sample averages: } & \multirow{3}{*}{$\begin{array}{l}\text { Average } \\
\text { savings } \\
\text { rate, } S / Y \\
\left(\begin{array}{c}0 \\
0\end{array}\right)\end{array}$} & \multicolumn{3}{|c|}{ Regression coefficients: } & \multirow{3}{*}{$\begin{array}{l}\text { Number of } \\
\text { observations }\end{array}$} \\
\hline & \multirow{2}{*}{$\begin{array}{l}\text { Land } \\
\text { owned } \\
\text { (acres) }\end{array}$} & \multirow{2}{*}{ 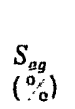 } & \multirow{2}{*}{$\begin{array}{l}\text { Income, } Y \\
\text { (Rs.) }\end{array}$} & & \multicolumn{2}{|c|}{ Eq. (2) } & \multirow{2}{*}{$\begin{array}{l}\text { Eq. (1) } \\
b\end{array}$} & \\
\hline & & & & & $b_{a}$ & $b_{o}$ & & \\
\hline \multicolumn{9}{|l|}{ Land categories } \\
\hline$<5$ acres & 2.6 & 63.9 & 2838 & 4.5 & $\begin{array}{c}0.24 \\
(2.73)\end{array}$ & 0.31 & 0.25 & 810 \\
\hline $5-15$ acres & 9.3 & 86.4 & 5099 & 12.6 & $\begin{array}{c}0.34 \\
(3.34)\end{array}$ & 0.47 & 0.35 & 743 \\
\hline$>15$ acres & 28.8 & 93.0 & 8716 & 21.4 & $\begin{array}{c}0.43 \\
(0.80)\end{array}$ & 0.49 & 0.43 & 427 \\
\hline \multicolumn{9}{|c|}{ Share of agricul! aral income $\left(S_{a g}\right)$} \\
\hline$<50 \%$ & 4.3 & 33.2 & 3322 & 8.9 & $\begin{array}{c}0.20 \\
(0.97)\end{array}$ & 0.38 & 0.35 & 360 \\
\hline $50-75 \%$ & 6.8 & 63.5 & 3773 & 9.4 & $\begin{array}{c}0.45 \\
(1.70)\end{array}$ & 0.20 & 0.36 & 365 \\
\hline$>75 \%$ & 13.8 & 96.0 & 5766 & 15.8 & $\begin{array}{c}0.39 \\
(1.98)\end{array}$ & 0.53 & 0.39 & 1255 \\
\hline All observations & 10.8 & 78.6 & 4959 & 14.1 & $\begin{array}{c}0.38 \\
(2.30)\end{array}$ & 0.43 & 0.38 & 1980 \\
\hline
\end{tabular}

Note: Values in parentheses indicate the absolute value of the $t$-statistic for the difference in the marginal propensities to save, $b_{a}$ and $b_{v}$. 
composition of income i.e. their permanent transitory mature. Nonagricultural income is mainly composed of wages and salaries from outside employment. Small farmers supplement their annual income with outside work since their own farms are not large enough to keep them fully employed. (O)utside income formed only 7 percent of total income for households owning more than fifteen acres.) Outide income, howerer, is likely to be more uncertain than on-farm income, since it is dependent on the probability of obtaining a job. Apart from its regular component, outside work is also resorted to under 'upecial' (and transitury') conditions of the family. Thus, $Y_{0}$ is likely to have a greater transitory component than $Y_{u}$, and if the MPS out of tancitory income is higher, then the observed propensilic.s to salle $\left(b_{a}\right.$ and $b_{n}$ in eq. (2)) can be explained by reference to transitury componenti.

Though plausible, the above interpretation remains conjectural. The permanent and transitory components of sources of income ale not usually identifiable with one-period data. However, the longitudinal aspect of the NCAFR data can be used to estimate the permanent and tramsitury componems (to be exalct. the dariances of each component) of each source of income. Thus, the "rariability of income" hypollesis of salsings can be empirically tested. The melhodology and empirical estimater follow.

\subsection{Saling. and the raruhility of income}

Analogous to Friedman (1957). each source of income is assumed to be composed of a permanent component $\left(Y_{a}^{\prime \prime}\right.$ and $\left.Y_{a}^{\prime \prime}\right)$ and a transitory component $\left(Y_{u}^{\prime \prime \prime}\right.$ and $\left.Y_{n}^{\prime \prime}\right)$. Further, the tramsitory components are assumed to be uncorrelated with the permanent components. Thus the following relationships hold:

$$
\begin{array}{ll}
Y_{i}=Y_{i}+Y_{i}^{\prime \prime}, & i=a, 0, \\
\text { (U) }\left(Y_{i}^{\prime \prime}, Y_{i}^{* \prime \prime}\right)=0, & i=a, 0 .
\end{array}
$$

Let $b^{\prime}\left(b^{\prime \prime}\right)$ represent the common propensity to save out of permanent (transilory) income. ${ }^{10}$ (jiven these assumptions, the 'true' model of sarings beharior is:

$$
S=a^{\prime}+b^{\prime}\left(Y_{a}^{\prime}+Y_{0}^{\prime \prime}\right)+b^{\prime \prime}\left(Y_{a}^{\prime \prime}+Y_{a}^{\prime \prime}\right)
$$

\footnotetext{
1"It is assumed that the propensity to save permanent income is unaffected by the source of the income. This asumption implies no more than the simple assertion that a (permanent) rupee is a rupee, segallalle il the source. A test of the assertion is beyond the scope of this paper. Holbrook and Sialfird (1971) found roughly constant permanent propensities to save out of different sources of income with II.S. data.
} 
An equation, estimated as in (1),

$$
S=a+b_{a}\left(Y_{a}^{\prime \prime}+Y_{a}^{\prime \prime}\right)+b_{b}\left(Y_{o}^{\prime \prime}+Y_{o}^{\prime \prime}\right)
$$

is mis-specified and $b_{a}$ and $b_{o}$ are biased estimates of the propensities to save, $b^{\prime}$ and $b^{\prime \prime}$. However, a relationship does exist between the observed propensities $b_{\mu}, b_{0}$ and the unmeasured propensities, $b^{\prime}$ and $b^{\prime \prime}$ i.e. ${ }^{11}$

$$
b_{0}-b_{a}=\left(b^{\prime \prime}-b^{\prime}\right)(A+B+C) \text {, }
$$

where

$$
\begin{aligned}
& A=\operatorname{var} Y_{o}^{\prime \prime} \text { var } Y_{a}^{\prime}-\operatorname{va} Y_{a}^{\prime \prime} \operatorname{var} Y_{o}^{\prime \prime}, \\
& B=\operatorname{cov}\left(Y_{a}^{\prime \prime}, Y_{o}^{\prime \prime}\right)\left(\operatorname{var} Y_{a}^{\prime \prime}-\operatorname{var} Y_{o}^{\prime}\right), \\
& C^{\prime}=\operatorname{cov}\left(Y_{a}^{\prime}, Y_{o}^{\prime}\right)\left(\operatorname{var} Y_{o}^{\prime \prime}-\operatorname{var} Y_{a}^{\prime \prime}\right)
\end{aligned}
$$

Since it can safely be assumed that $b^{\prime \prime}>b^{\prime}$ (see note 6), the observed results $b_{o}>b_{a}$ can only occur if $(A+B+C)>0$. If the cxtreme assumption is made that the covariances hetween the permanent and transitory components $\left[\operatorname{cov}\left(Y_{u}^{\prime \prime}, Y_{0}^{\prime}\right)\right.$ and $\left.\operatorname{cov}\left(Y_{u}^{\prime \prime}, Y_{b}^{\prime \prime}\right)\right]$ are zero, then $b_{a}$ and $b_{0}$ are cyual to

$$
\begin{aligned}
& b_{a}=b^{\prime}\left(\operatorname{var} Y_{a}^{\prime \prime} \operatorname{var} Y_{a}\right)+b^{\prime \prime}\left(\operatorname{var} Y_{a}^{\prime \prime} / \operatorname{var} Y_{a}\right), \\
& b_{0}=b^{\prime}\left(\operatorname{var} Y_{o}^{\prime \prime} \operatorname{var} Y_{o}\right)+b^{\prime \prime}\left(\operatorname{var} Y_{o}^{\prime \prime} / \operatorname{var} Y_{o}\right) .
\end{aligned}
$$

In other words, $b_{a}$ and $b_{a}$ are weighted averages of the shares of permanent and transitory income in each source of income: and the statement that differences in observed propensities merely reflect the pemanentitransitory nature of different income streams is cerified if $b_{0}>b_{a}$ is observed along with

$$
\operatorname{var} Y_{v}^{\prime \prime}: \operatorname{var} Y_{o}^{\prime}>\operatorname{var} Y_{a}^{\prime \prime}: \operatorname{var} Y_{a}
$$

The exactitude of the ahoric statement is lessened if one allows for the possibility that the two corariances, $(1) \cdot\left(Y_{a}^{\prime}, Y_{a}^{\prime \prime}\right)$ and $\operatorname{cov}\left(Y_{a}^{\prime \prime}, Y_{0}^{\prime \prime}\right)$ are noncro. In particular, if sither $B$ or $C$ is positive it can no longer be asserted that $b_{0}>b_{a}$ hecaluse $Y_{o}$ has a greater transitory component than $Y_{a}$. On the other hand. if $B$ and $C$ are both negative, then one has the 'strong' result that $b_{0}>b_{a}$ because of differences in the transitury nature of incomes. The liketihnod of such a result is examined first by looking at ine expected sign of terms $B$ and $C$, and later their magnilude.

\footnotetext{
"See Bhalla (1976a) for algebraic del:uh.
} 
On an a priori basis, one would expect the term $\operatorname{cov}\left(Y_{a}^{\prime \prime}, Y_{0}^{\prime \prime}\right)$ to be negative for a given point in time. This is because a household is expected to maintain a given level of total income-unexpected changes in one source are partially made up by opposite change: in other sources of income. However, one factor that might cause the corrclation to be posilire should be mentioned namely, the weather. One component of non-agricullural income is the wages calrned on agriculturul land of non-family households and it is expected that incomes from this source will move in the same direction as agricultural incomes. ${ }^{12}$ The net result is therefore ambiguous, though it is likely that the correlation will be negatice.

Amongst groups classified by land holdings, one would expect the correlation between the permanent compunents $\left(Y_{a}^{\prime}, Y_{n}^{\prime}\right)$ to be positive. This is because it is expected that factors like education and access to murket affect both incoms simultaneously. If these factors are associated positively with other determinants of on-farm income (land, other assets), then a "high "ducition" household is likely to have a higher on-farm income as well as higher off-farm income in the form of salaries, non-farm business etc. However, if the clamification of households is sufficiently broad, this correlation can be negative. For instince, a large land owning houschold is likely to keep its fanily members employed on the farm, whilst a umbll farm houschold is lihely to upplement its labor income with work off the farm. The probahility of a negative correlation amongse the permanent components is reduced (but not climinated) by the fact that household have been clatsified into relativaly homogeneous groups.

The terms ( 1 ar $\left.Y_{a}^{\prime \prime}-\operatorname{var} Y_{n}^{\prime \prime}\right)$ and (var $\left.Y_{n}^{\prime \prime}-\operatorname{var} Y_{a}^{\prime \prime}\right)$ need to be cximnined before the sign of $B$ and $(C$ are determined. If the (reasonale) assumption is made that each source of income has approvimaltely the same cosfficient of vartiation, i.e.

$$
\operatorname{var} Y_{u}\left(Y_{u}\right)^{2}=\operatorname{var} Y_{n}\left(Y_{u}\right)^{2}, \quad \dot{Y}_{u}, Y_{n} \text { are mean vilues. }
$$

and ir. agricultural income is a maljor part of income. ${ }^{1.3}$ (i.e. $\bar{Y}_{a}>\bar{Y}_{o}$ ), then it follow: that (var $Y_{a}^{\prime \prime}-$ var $Y_{n}^{\prime \prime}$ ) is poritise when non-ilgricultural income has a grealer tramsitory component. ${ }^{14}$ Additional restrictions are necessary to ansign a sign to (var $Y_{n}^{\prime \prime-}$ var $Y_{n}^{\prime \prime \prime}$ ): the empirical eridence, howerer, strongly uggests that this is negalive when non-igricultural income is more tramsitory

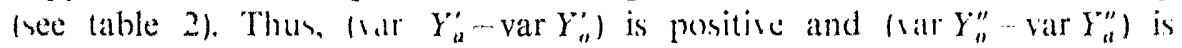

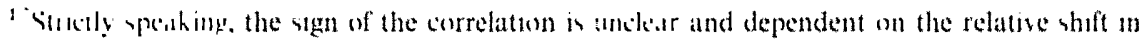

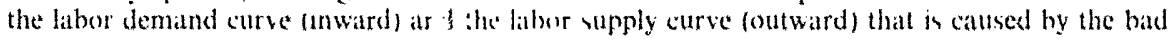
willher

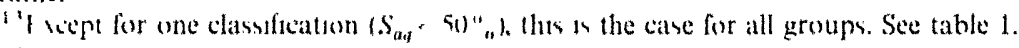

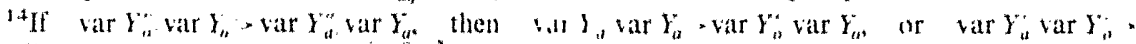
var $Y_{a}$ var $Y_{z}$ or var $Y_{a}^{\prime}$ var $Y_{a}^{\prime}=\left(Y_{a} Y_{a}^{\prime}\right)^{2} \cdot 1$.
} 
experted to be negitio. This coupled with the assumption that $\operatorname{cov}\left(Y_{a}^{\prime \prime}, Y_{b}^{\prime \prime}\right)$ is

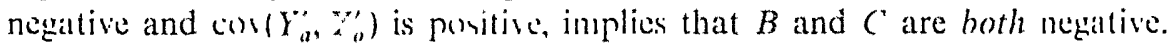
Thus, under 'expected' conditions, one obtains the 'strong' result that $h_{0}>h_{a}$ when mon-agricultural income is more trambitory than agricultural income.

lion if the corrolations are of the 'wromg' sign, it is likely that the mignitudes of $B$ and $C$ are much smaller than $A$, and therefore negligible. Frpanding terms $A, B$, and $C$ one obtains

$$
\begin{aligned}
& \operatorname{var} Y_{a}^{\prime \prime}\left(\operatorname{var} Y_{a}^{\prime \prime}+\operatorname{cov}\left(Y_{a}^{\prime \prime}, Y_{n}^{\prime \prime}\right)\right)+\operatorname{var} Y_{a}^{\prime}\left(\operatorname{var} Y_{a}^{\prime \prime}+\operatorname{cov}\left(Y_{a}^{\prime \prime}, Y_{0}^{\prime \prime \prime}\right)\right) \\
& \left(\operatorname{cov}\left(Y_{a}^{\prime}, Y_{n}^{\prime \prime}\right)\left(\text { var } Y_{n}^{\prime \prime}, \cdots \operatorname{var} Y_{a}^{\prime \prime}\right)>0 \text {, for } b_{0}>b_{a}\right. \text {. }
\end{aligned}
$$

If the variances are much larger than the condriance", as expected, then the pusitive nature of cov $\left(Y_{a}^{\prime \prime}, Y_{n}^{\prime \prime}\right)$ add only a negligible amount to the first two terms. Further, the (small) negatio sovariance helween the permanent components is multiplied by the difference between the transitory variances. Thus it appears that a strong test of the "rariability" hypothesis of salvings is the ansuciation of the observed propensities $b_{0}>b_{a}$, with the relationship var $Y_{* \prime \prime}^{\prime \prime} \operatorname{var} Y_{n}>\operatorname{var} Y_{a}^{\prime \prime}$ var $Y_{n}$.

Tho absmplioms are necensaly an order to isolate the variances of the permanemt and tramslory components. Firstly, it is assumed that tramstery menmes. astadlem of whices, are uncorrelated with each wher for the first and third year of the survey" "The secomel asimption concerms the colitionship between the permanent components of the first and third jear. Growth in incomen is expected to catse a sysematic desiation between the two valiables. (irowh in actual incomes for indis idual households cammot be used to whimate espectatims about permanent income since these incomes are contaminated by the (mmmedsured) tramsitury component. Further, the growh experienced during the three years by an individual household maj" nor be a valid indicillor of its epepeded profile of permanent income. A plamible atsumption is that farm houscholds adjust their expectations about growth in permancent income by the arerage growth experience of similar households. This is the aramption used in this paper; though questionahle, it should be emplabused that the clissification of farm houscholds into

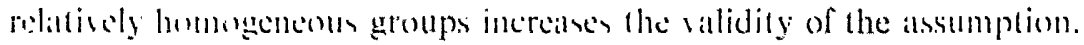

If the fi.st feill vilue are represemled by lower case letters, the assumpliom are as follows:

$$
\cos \left(l_{i}^{\prime \prime}, Y_{i}^{\prime \prime}\right) \rightarrow 0, \quad i \cdots, 0 .
$$

\footnotetext{
$1^{4}$ A pero correlation hetween tranbitory lerm two years apall imples a hurbon" of thace

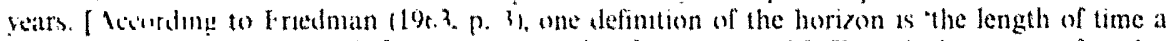

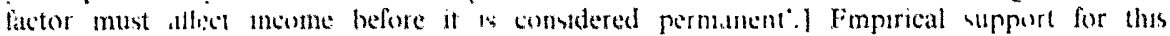
assumpton is pronded in Bhalla $(19, \cdot, b)$ where 11 is shown that three years is an upper bound estimate of the horizon for farm households in India.
} 


$$
\begin{array}{ll}
y_{a}^{\prime}=g_{a} Y_{a}^{\prime}, & g_{a}=\mathrm{E}\left(y_{a}\right) / \mathrm{E}\left(Y_{a}\right), \\
y_{o}^{\prime}=g_{o} Y_{o}^{\prime}, & g_{o}=\mathrm{E}\left(y_{o}\right)_{i} \mathrm{E}\left(Y_{o}^{\prime}\right) .
\end{array}
$$

Eqs. (3) and (8), and the covariances of income in the first and third year of the survey are enough to isolate the variances of permanent and transitory components of income:

$$
\begin{aligned}
\operatorname{cov}\left(y_{a}^{\prime}, Y_{a}\right) & =\operatorname{cov}\left(y_{a}^{\prime}+y_{a}^{\prime \prime}, Y_{a}^{\prime}+Y_{a}^{\prime \prime}\right), \\
& =\operatorname{cov}\left(y_{a}^{\prime}, Y_{a}^{\prime}\right), \\
& =g_{a} \operatorname{var} Y_{a}^{\prime} .
\end{aligned}
$$

Analogously,

$$
\cos \left(y_{0}, Y_{0}\right)=g_{0} \operatorname{var} Y_{0}^{\prime} .
$$

Eqs. (9a) and (9b) allow one to estimate the variances of the permanent components. Estimates of the transitory variances are obtained from the relationship,

$$
\operatorname{var}\left(Y_{i}^{\prime}\right)=\operatorname{var} Y_{i}^{\prime \prime}+\operatorname{var} Y_{i}^{\prime \prime \prime}, \quad i=a, o .
$$

Table 2 presents the results for the estimated proportions of income variance, by source and type of income. Fstimates of $b_{0}$ and $b_{a}$, reported in table 1 , are also presented. It is observed that the result $b_{n}>b_{a}$ is alwalys associated with the result $\operatorname{var} Y_{n}^{\prime \prime}$, var $Y_{n}>\operatorname{var} Y_{a,}^{\prime \prime \prime}$ var $Y_{a}^{\prime}$. In the one case that $b_{a}>b_{o}$, the opposite (and consistenl) result that var $Y_{n, i}^{\prime \prime \prime}$ var $Y_{o}^{\prime}<\operatorname{var} Y_{a}^{\prime \prime} / \operatorname{var} Y_{a}$ is obtained.

These results confirm, in a rather striking manner, the Friedman hypothesis that differences in the propensities to save, $b_{0}$ and $b_{a}$, are observed because of differences in the variability of income streams. This result is not inconsistent with the observed positive relationship between the share of income derived from agriculture (and land ownership) and savings. However, the latter result cannot be interpreted to be in support of the hypolhesis that entrepreneurial income (and/or investment opportunities) are positively related to savings for two reasons: (a) mean income levels also increase with the saving rates of the groups, and therefore might be a major caluse of the observed result, and (b) within group regressions resulted in propensities to save being higher out of non-agricultural income.

\section{Investment opportunities and savings: $\mathbf{A}$ theoretical discussion}

The previous section discussed the use of an indirect method for deriving 
Table .

Variability in different sources of income.

\begin{tabular}{|c|c|c|c|c|c|c|c|}
\hline & \multicolumn{3}{|c|}{ L.and-ıwing c:ttegorics } & \multicolumn{3}{|c|}{$\begin{array}{l}\text { Share of agriculiural } \\
\text { income }\end{array}$} & \multirow[b]{2}{*}{$\begin{array}{l}\text { All } \\
\text { observations }\end{array}$} \\
\hline & $\begin{array}{l}<5 \\
\text { acres }\end{array}$ & $\begin{array}{l}5 \cdots 15 \\
\text { acres }\end{array}$ & $\begin{array}{l}>15 \\
\text { acres }\end{array}$ & $<50^{\circ}$ & $50-75^{\circ}$ & $>75 \%$ & \\
\hline Mean, $Y_{u}$ & 319 & 659 & 1060 & 159 & 330 & 816 & 607 \\
\hline Std. dev., $Y_{a}$ & 315 & 585 & 906 & 150 & 260 & 722 & 652 \\
\hline Mean, $Y_{0}$ & 153 & 89 & 63 & 318 & 188 & 26 & 109 \\
\hline Std, dev, $Y_{\theta}$ & 176 & 189 & 205 & 267 & 157 & 94 & 191 \\
\hline Nean, $y_{a}$ & 316 & 572 & 859 & 228 & 343 & 670 & 529 \\
\hline Std. dev., $y_{a}$ & 363 & 582 & 797 & 294 & 355 & 672 & 601 \\
\hline Mean, $y_{o}$ & 186 & 123 & 117 & 281 & 177 & 100 & 147 \\
\hline Std. dev., $y_{0}$ & 383 & 221 & 246 & 486 & 222 & 237 & 304 \\
\hline $\operatorname{corr}\left(Y_{u}, y_{u}\right)$ & 0.564 & 0.537 & 0.453 & 0.593 & 0.548 & 0.494 & 0.559 \\
\hline $\operatorname{corr}\left(y_{0}^{*}, y_{0}\right)$ & 0.241 & 0.499 & 0.411 & 0.290 & 0.593 & 0.148 & 0.357 \\
\hline var $Y_{u}^{\prime \prime}$ var $Y_{a}$ & 0.34 & 0.38 & 0.51 & 0.19 & 0.28 & 0.44 & 0.41 \\
\hline $\operatorname{var} Y_{a_{2}}^{\prime \prime}$ var $Y_{0}^{\prime \prime}$ & 0.57 & 0.58 & 0.73 & 0.40 & 0.11 & 0.90 & 0.58 \\
\hline $\operatorname{MPS} Y_{a}, b_{a}$ & 0.24 & 0.34 & 0.43 & 0.29 & 0.45 & 0.39 & 0.38 \\
\hline $\operatorname{MPS} Y_{0}, b_{0}$ & 0.31 & 0.47 & 0.49 & 0.38 & 0.20 & 0.53 & 0.43 \\
\hline
\end{tabular}

Notes: (1) lipper case lower case represent third year first year values.

(2) $Y_{4}^{\prime \prime}, Y_{n}^{\prime \prime}$ represent the transitory components of agricultural and non-agricultural income, respectively.

the response of investment opportunities to saving. The importance of this subject was emphasized by Schultz (1964), who, in his classic study on traditional agriculture, stated that although there has been a long standing concern about the effects of the level of per family income upon percentage of income that is saved, there has been no comparable concern about the effect of difference in relative prices of new income streams upon savings and investment' (1964, p. 74). It is the purpose of this section to test directly' the effect of investment opportunities on savings.

The term 'investment opportunity' was first formalized by Irving Fisher. He defined it as follows: "The concept of investment opportunities rests on that of an "option". An option is any possible income stream open to an individual by utilizing his resources, capital, labor, land, money, to produce or secure said income stream. An investment opportunity is the opportunity to shift from one such option, or optional income strean, to another' (1934, p. 151). For farm households such as those analyzed in this paper, an investment opportunity can be defined to be a perceived shift in their production possibilities.

The green revolution years of the late sixties provide a rare and ideal representation of shifts in production possibilities. The introduction of high yielding varieties (HYV) afforded farmers the chance to increase significantly their rates of return from investment; this investment opportunity meant 
increased profits from both old capital (irrigation) and irom new investments. But did this improvement in the return to existing and additional capital result in more short-run savings on the part of farm households?

The effect of investment opportunities on saving: is analogous to the effect of interest rate on savings, e.g. Wright (1967), Weber (1970). These studies, however, were done in the context of time series data with all households assumed to face the same rate of interest. In this paper, cross section variation in the investment opportunities faced by otherwise identical households plays the role of interest rate variation in time-series studies. The variation in investment opportunities is best illustrated by fig. 1, which shows

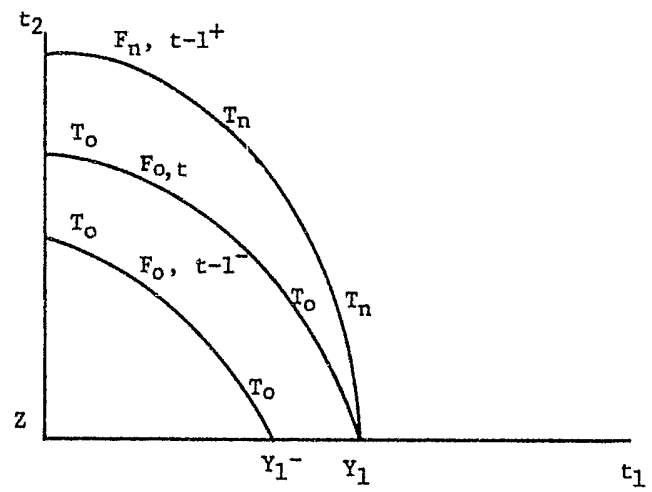

Fig. 1. Investment opportunity loci faced by $F_{0}$ (old technology farmer) and $F_{n}$ (new technology farmer).

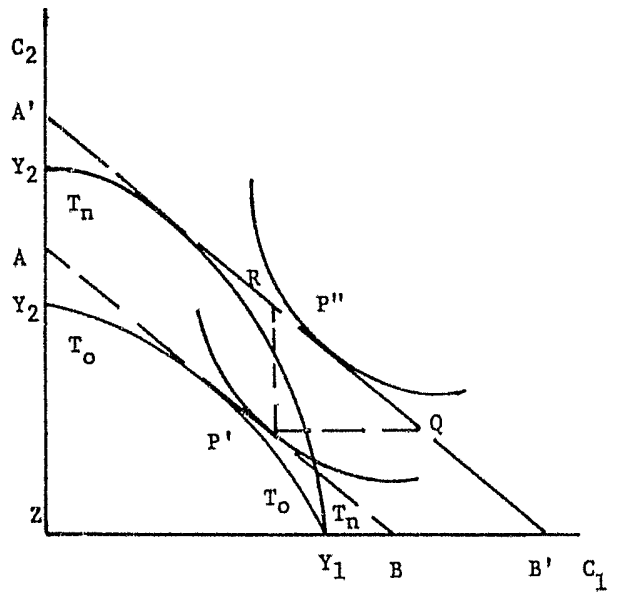

(a) Perfect Capital Market

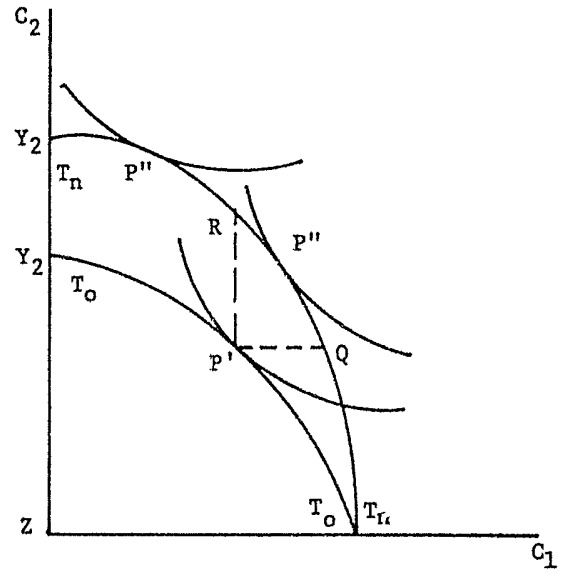

(b) No Capital Market

Fig. 2. Investment opportunities and savings. 
the technology frontier $\left(T_{0} T_{0}\right)$ faced by an old technology farmer, $F_{0}$ (e.g. farmer in a Bihar district) and the frontier $\left(T_{n} T_{n}\right)$ faced by a new technology farmer, $F_{n}$ (e.g. farmer in a Punjab district). Prior to the introduction of the HYV's, in time period $t-1, F_{\mathrm{n}}$ earns an income $Y_{i}$ which is less than the inconce earned by $F_{0}$. (Implicit assumption is that $F_{n}$ owns a smaller acreage of quality adjusted land than $F_{0}$ ) With partial and immediate adoption of HYV's $F_{n}$ now faces a new technology fronticr, $T_{n} T_{n}$, in time period $t-1^{+}$ and beyond. Since the analysis pertains to "otherwise identical' houscholds, both farmers are shown to have the same first period incoms. $Y_{1}$. With investments, each farmer can enjoy a higher income in period $2, Y_{2}$, by moving along his technology frontier. (Note that intestments only affect income in future period: $Z$ is second period income with zero first period investment.) $T_{n} T_{n}$ is shown to have a higher slope at each investment point in order to incorporate the assumption that the new techology is more profitable.

The theoretical relationship between investment opportunities and sidings can be shown by use of diagrams similar to fig. 1. These two-prerind diagrams illustrate the optimal consumplion and investment decision on the part of a farm houschold. ${ }^{16}$ These decisions are crucially affected by the nature of the capital marke in which the household operalles: thus, two polar cases are analysed (1) a perfect capital marhet (rich farmers). fig. 2a, and (2) no capital marhel or a Robinson Crusoe ecomomy (poor farmers), fig. 2b. In both figures, the comparison is between similar farmers (ectual first period income) facing different productice (investment) opportunities. $C_{1}$ and $C_{2}$ represent present and future consumption, $P^{\prime}$ and $P^{\prime \prime}$, the squilibrium points, and $A B$ the (exogenous) rate of exchange hetween the two periods.

In the case of a perfect capital market. the shift in the opportunity locus $\left(T_{0} T_{0}\right.$ to $\left.T_{n} T_{n}\right)$ implies an increare in wealth $\left(A B\right.$ to $\left.A^{\prime} B^{\prime}\right)$ with the relative price of consumption in each period (i.e. the inlerest rate) held constant. Thus, there is no iuhstitution effect (change in relative prices) involved with a change in the locus. If it is now assumed that comsumption in each period is a superior good, then the point of tangency for farmer $F_{n}, P^{\prime \prime}$, has to be in the triangle, $P^{\prime} Q R$, representing increalses in consumplion in both time periods (wealth effect). Thus, first period comsumption is higher, and sidings lower. for houschold, with greater investment opporlunitis: i.e. rich new technology farmers rate less than ich old technology farmers if credit is freely arailable.

In the self-linance world of Robinson (rusos, the effect of a shift in the lechnology locus on first period imutment (savings) is a priori ambiguous. As shown in fig. 2b, comsumption in the first period can either incease or

\footnotetext{
1the theory of inter-temporal cholce (1)plimal investment decision) was developed by Fisher and elaborated by Hirshleifer ! $135 x, 197(1)$. The reader is refered to 11 inhleifer for a detailed analysis of investment choice in the context of a $($ wo - periul model.
} 
decrease. The reason for the ambiguity is the simultaneous presence of both wealth and substitution effect associated with the change in technology. The point of tangency for farmer $F_{n}$ will be the left of $\mathrm{P}^{\prime}$ (more first period savings) if the substitution effect dominates the wealth effect. ${ }^{17}$

The arnbiguity in the savings hehilvior can be removed if one makes the (realistic) assumption that 'lumpy' investments are needed for a successful adoption of the new technology. In this instance, $T_{n} T_{n}$ might not be the appropriate representation of the technology faced by the Punjabi farmer. Even though $F_{n}$ has increased the flow of income by adoption of the new technology on available irrigated land, further 'lumpy' investments in irrigation and land improvement may be necessary to successfully adopt the new technology. In a Robinson Crusne economy, the resources for this additional investment can only come from increased savings. Thus, in fig. $2 \mathrm{~b}$, if savings greater than $Y_{1}-P^{\prime}$ are needed for transfer to $T_{n} T_{n}$, then those households planning to use the new technology have to save greater than $Y_{1}$ $-P^{\prime}$ in the 'transformation' years. Hence, poor new' technology farmers are likely to save more than poor old technology farmers. Thus, if discrete investments in the new technology are possible, the effect of investment opportunities on savings is ambiguous: if suflicient 'lumpiness' is allowed for, the effect is positive. ${ }^{18}$

In summary, the theoretical results indicate that the effects of investment opportunities on savings depend on as:iumntions about the capital market. In a perfect capital market case, the effect is an unambiguous decline in savings. ${ }^{19}$ In a self-finance economy, the effect is ambiguous, unless lumpy investments are assumed. In the next section, an index reflecting the different investment opportunities is constructed, and the propositions outlined above are empirically tested.

\subsection{Investment opportunity: Construction of index and empiricul results}

The households covered by the NCAER survey presumably face different marginal rates of return on any new investment. This likelihood is enhanced by the fact that the period covered by the survey 1968-69 to 1970-71encompases the years when the new technology was being adopted by farms in India. However, the construction of an index which will reflect

\footnotetext{
${ }^{17}$ The wealth effect of an increase in investment apportunities is dependent on the size of savings. For poor people, this, and comsequently the wealth effect, is lixcly to be small. This is another argument for expecting the net effect of a change in productive opportunitien to be positive for poorer farmers.

${ }^{18} \mathrm{M}$ ckinnon $(1973, \mathrm{p} .13)$ als.) uses the lumpiness in investment issumpliun to argue that a lack of access to external funds implies that the constraint of sell-linance sharply biases investment strategy toward inarginal variations within the :radıtiınal technolugy".

${ }^{19}$ In the case of an imperfect capital market, the effect is ambiguous, a priori, and dependent on assumptions about the relative costs of borrowing and returns from investment.
} 
differences in the percived rate of return on investments is not an easy task. Any attempt to construct such a meisure is fraught with dillicultics: nevertheless, the index should incurporate the following factors:

(a) Adoption status (HYY (ultirution'non-HYV (ultiration) of households: The reason for including this information is obvious. The new technology, if adopted properly, can significantly increase the returns from cultivation.

(b) Extent and type of irrigation: The new technology is heavily dependent for its slccess on the availability and controlled supply of water. A tube well investment may therefore be expected to yield different returns than a canal irrig:ttion ș stem.

(c) Regional lincution: Land differences are likely to affect the profitability of certain investments: further, the perceptions of a farmer in a successful area of the green revolution (e.g. Punjab) probably differs systematically from those of an identical farmer in an unsucesssful region (e.g. Bihar).

(d) Cropping pattern: The cullisition of wheat has proved to be more profilable than the cullivation of rice. Identical on-farm investmente, when used in the producton of different crops, are likely to yield different returns.

(e) Fertilizer and credit: Successul aldoption of the new technoluges is dependent on the atailability and proper application of fertilisers, pestictes: etc. Working capital requiremenls increalse significantly with the new tochnology: thus, alcein to working capital, and its cost, affects the perceived profitability of the new technology:

The above list of relevant factors affecting an investment opportunity index

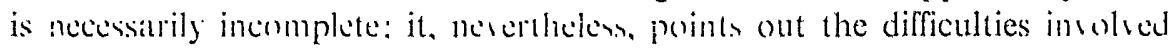
in the construction of such an index. A proper definition of an index notwithstinding, the purpose of this section remains the testing of an in eviment opportunity effect on sarings. The previous discussion has made clear that the adoption status of a household should be included in any ansessment of the rates of return perceived by a household. Thus, it might seem apprepriale to classify households according to whether they have, or have not, adopted the technology. This 'index', however, has several drawbacks. It altributes equal opportunities to an adopter regalrdless of the crop grown, or its regional location. Most importantly, it altribules no insestment opportunity to a farmer who might very well be on the verge of adoption.

An alternative index of differing pereeptions of insentment opportunities is the aldoption rate of the new technology in the district in which a hourchold resides. Soil quality, pattern of crops produced (wheat, rice, etc.) presence of extension programs, credit alsailability (government, co-opelatives etc.) are all variables which vary more amongul districts than amongst households within a district. Differences in profitability of investment between regions should be 
reflected in differences in district adoption rates. Moreover, use of this index assigns the same investment opportunity (IO) to all houscholds within a district, regardless of whether any individual household had actually adopled the technology. Comparing non-adopters, it is likely that a farm household in a Punjab district perceives a greater investment yield on its opportunities than a household in a Bihar district, and differences in district adoption rates should reflect this perception.

Though not perfect, the district adoption rate comes closest to a desired index of investment opportunities. The NCAER survey contains data for 2952 cultivator households in 1970.71. These households were aggregated into 100 districts, and a weighled percentage of adopter households was estimated for each district. ${ }^{20}$ This percentage was then assigned as an $I O$ index to each household within the district. Since the analysir of savings is for the third year of the survey, perceived opportunities of a household are likely to be based on past rates of adoption. Consequently, district adoption rates for the seconil year of the survey were chosen for analysis.

The hypothesis to be tested is whether, ceteris paribus, investment opportunities have a positive effect on savings. An important determinant of savings which one would like to control is the permancint income of a homichold, $Y_{p}$. (This roughly corresponds to the flow of income proportional to $Y_{1}$ in fig. 2.) This, however, causes additional problems. Whall measure should one use for permanent income? In Bhalla (1976a), two conceptually different incisurus of permanent income $\left(Y_{p}\right)$ were constructed. Considerations of discount rates, expected income and expected growth in income dictated one measure, $Y_{n i}$. Thus, a discount rate of 35 percent, (corresponding to a three year horizon see note (15), and an expected growth rate in incomes of 3.5 percent per year, yields

$$
Y_{p i}=0.437 Y_{0}+0.374 Y_{1}+0.275 Y_{2} \text {. }
$$

where $Y_{0}$ is measured income, 1970-71.

An earnings function approuth dictaled the other measure of permanent income, $Y_{p x}$. This method relates the delerminants of income $(X)$ to measured income, $Y$; i.e. the regression

$$
Y=b_{0}+b_{1} X_{1}+b_{2} X_{2}+\ldots \ldots b_{n} X_{n}+c^{\prime}
$$

is estimated and predicted values of $Y, \hat{Y}$, are taken to be estimates of permanent income. Though aceeptable, there is a serious problem with this approach. The residuals $(Y-\hat{Y}=\hat{e})$ rather than identifying the alssumed

\footnotetext{
${ }^{20}$ The NCAER survey did not sample its respondents on a random basis: comeopuently, population weights are used to obtain estimites on a district hasis.
} 
transitory components of income, might reflect just the opposite, i.e. differences in permanent levels. The panel nature of the NCAER data aroids this bias and makes possible an improved 'earnings function' estimate of $Y_{p}$; in particular, it allows for the decomposition of the error term $e_{i}$ into an unobserved permanent component $\hat{i}_{i}$ and a 'true' error term, $c_{i}$. This fixed effects' error components model yields

$$
Y_{p x}=\hat{\gamma}_{i}+0.182 H+0.33 K+188.7 L+5.6 T \text {, }
$$

where the determinints of income are individual constants $(i, 1)$ land value $(H)$, capital assets $(K)$, fumily lithor $(L)$, and the level of technology $(T)$. [For details on the construction of the measures $Y_{p i}$ and $Y_{p x}$, see Bhalla (1976a).]

In order to provide a partial check on the robus!ness of the results, both measures of permanent income are used in the empirical analysis. For silke of a 'complete' anilysis, tests using current income (argued by some to be the relevant variatble for savings behavior) for 1970. 71 are also presented.

One problem rematins how should households be classified into 'Robinum ('rusoes" and "perfect capital market' economies. It is difficult to assert that any rural houschold in India falces a perfect capital market. Howewer. an

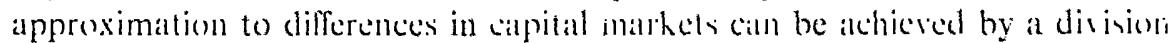
of households into self-finance and open access" culleguries. If the wealth (permanent incomel of a houschold is indicative of its ability to burrow, then the arbitrary (but plausible) division of households into subislence, nonsubsistence categories is meiningful. Identification of a subsistence level, however is a difficult matter. The subject has been discussed at length in the Indian literature and the general consensus seems to be that an annual income of Rs 450 per capita, 1970) 71 prices (correspondin! to Rs 15 Rs 20 per month, 1960-61 prices) adeyuately describes the subistence (or poverty) level. Thus, households have been clasmified acording to whether their average per capita income, $Y_{a p r}$ was above or below Rs 500 a conservalice estimate of the subsistence level 21 Though the non-subsistence group is unlikely to face a perfect capitil market, it is iikely that its alcesss is considerably greiler than the subsistence group.

If the index of investment opportunities, $I O$, is presumed to be roughly indicative of differences in rates of return earned by the houseluold, then the effect on silvings of 10 can be terted by chtimalting eq. (11):22

\footnotetext{
${ }^{21}$ The choice of $I_{a m}$ (ratuo of the sum of llace year incomes and family sizes) as a climblicillon variable was dictated by the need to have a common sample of houscholds for compurisun of the estimates yielded by the two "preferred" measures of permanent ancome $Y_{p t}$ and $Y_{n v}$.

${ }^{22} \mathrm{~A}$ level hegression in savings, estimated an in eq. (11) results in errors whose vartance increase with permanent income. If the andmptim is made that the variance of the residuals Increases with the square of permanent incomes then the helemededsticily present in ey. (11) can be corrected by deflutm! all vatrables by permanent income. All cytutiom have been estimated with this currecilion for heteroscedavticity.
} 


$$
S=a_{1}+a_{2} I O+b_{1} Y_{p}+b_{2} Y_{t}+e^{2}
$$

where all variables are in per capita lerms, and $Y_{p}\left(Y_{t}\right)=$ permanent (transitory income) of household, $1970 \cdots 71,10=$ investment opportunities index (weighted district average of the adopters of new technology, 1969 70).

This equation (with the rate of interest on savings, $r$, replacing $I O$ ) is similar to those estimated for the U.S. [see C. Wright (1967), Weber (1970) and L. Taylor (1971)]. These authors make the assumption that $r$ reflects both the cost of borrowing and the return on lending. Due to the presence of opposing income and substifution effects, this causes the coefficient of $r$ to be ambiguous on an a priori basis. The results pertaining to eq. (11) are not strictly comparable. The alsimmplions regarding the capital market - in particular, that subsistence houseliolds are likely to nbtain little credit for investment, and that non-subsistence households obtain such credit at relatively constant rates of interest-remove some ambiguity about the sign of $a_{2}$. The coefficient is predicted to be positive for poor households and negative for non-subsistence.

The empirical results strongly support these assertions (see table 3 ). ${ }^{23}$ For the subsistence group, coefficient $a_{2}$ is positive: holding constant the level of permanent income, poor households with greater investment opportunitics save more. (Coefficient $a_{2}$ is significant at the 5 percent level; for $Y_{p x}$. significance is at the 10 percent level, two-tailed test.) Members of the nonsubsistence group (heller access to a capital market) decrease their savings in response to an increase in investment opportunities. ${ }^{24}$ (Coefficient $a_{2}$ is negative and significant at the 1 percent level). It should be emphasized that this is a partial effect: it is not contended that richer households save less, or at a lower rate (note that the non-subsistence group has a MPS out of $Y_{p}$ of 0.36: the corresponding figure for the subsistence group is 0.11 ).

The results are invariant with respect to the particular measure used to represent permanent income. This robustness in the results, as well as the fact that the sign of the $1 O$ coefficient, $a_{2}$, changes in a predictable fashion for different income sruups, supports the contention that the effect of investment opportunities on savings cannot be viewed in isolation. The firm houseluld nature of farm families makes it imperative that capital market conditions be explicitly incorpurated into the analysis.

\footnotetext{
'Similir results are obtained if the marginal pupeusity to save out of permanent ineome is allowed to vary with investment opportunities [addulan if term $b_{2} \cdot Y_{p} \cdot 10$ in eq. (11)] and $a_{2}$ assumed to be zero. Allwing for thanges in both $a_{2}$ and $b_{2}\left(a_{2} \neq 0, h_{2}=11\right)$ introduces

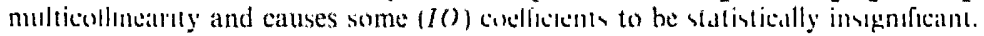

${ }^{24}$ If non-subsistence bouseholds are sub-divided into group earning above and below Rs. 1.50) per capita, then :le cocilickm $a_{2}$ is negative, but not inmficim (at the 5 percent level) for tife richest group. This "incomsinemi" result for the rich households (top 1 percent of the mral population) may be due to the small simple sice 1125 obsersaioms and the relatively lower variation in the investment opportunities index.
} 
Table 3

Effect of investment opportunities on savings.

\begin{tabular}{|c|c|c|c|c|c|c|}
\hline & \multirow[b]{2}{*}{ Constant } & \multicolumn{3}{|c|}{ Coefficients (eq. 11) } & \multirow[b]{2}{*}{$\bar{R}^{2}$} & \multirow[b]{2}{*}{$\begin{array}{l}\text { Standard } \\
\text { error }\end{array}$} \\
\hline & & $\begin{array}{l}\text { Investment } \\
\text { opportunity } \\
a_{2}\end{array}$ & $\begin{array}{l}\text { Permanent } \\
\text { income } \\
b_{1}\end{array}$ & $\begin{array}{l}\text { Transitory } \\
\text { income } \\
b_{2}\end{array}$ & & \\
\hline \multicolumn{6}{|c|}{ Subsistence } & $Y_{a p c} \leqq \mathrm{Rs} .500(N=915)$ \\
\hline$Y_{p}=Y_{p x}$ & $\begin{array}{c}-41.4 \\
(7.3)\end{array}$ & $\begin{array}{l}15.6 \\
(1.7)\end{array}$ & $\begin{array}{r}0.11 \\
(5.8)\end{array}$ & $\begin{array}{r}0.20 \\
(8.9)\end{array}$ & 0.11 & 0.1927 \\
\hline$Y_{p}=Y_{p t}$ & $\begin{array}{r}-41.2 \\
(7.3)\end{array}$ & $\begin{array}{c}20.6 \\
(2.2)\end{array}$ & $\begin{array}{r}0.11 \\
(6.0)\end{array}$ & $\begin{array}{r}0.21 \\
(8.2)\end{array}$ & 0.11 & 0.1942 \\
\hline$Y_{p}=Y$ & $\begin{array}{c}-52.4 \\
(10.8)\end{array}$ & $\begin{array}{l}21.6 \\
(2.3)\end{array}$ & $\begin{array}{r}0.14 \\
(8.2)\end{array}$ & & 0.11 & 0.2133 \\
\hline \multicolumn{7}{|c|}{ Non-subsistence } \\
\hline \multicolumn{7}{|c|}{$Y_{a p c}>$ Rs. $500(N=1065)$} \\
\hline$Y_{p}=Y_{p x}$ & $\begin{array}{r}-181.3 \\
(13.4)\end{array}$ & $\begin{array}{r}-62.0 \\
(3.7)\end{array}$ & $\begin{array}{r}0.38 \\
(22.0)\end{array}$ & $\begin{array}{r}0.33 \\
(16.9)\end{array}$ & 0.31 & 0.1984 \\
\hline$Y_{p}=Y_{p i}$ & $\begin{array}{r}-163.6 \\
(12.6)\end{array}$ & $\begin{array}{r}-57.4 \\
(3.5)\end{array}$ & $\begin{array}{r}0.36 \\
(22.0)\end{array}$ & $\begin{array}{r}0.36 \\
(16.6)\end{array}$ & 0.31 & 0.1927 \\
\hline$Y_{p}=Y$ & $\begin{array}{r}-130.6 \\
(14.2)\end{array}$ & $\begin{array}{r}-42.3 \\
(2.9)\end{array}$ & $\begin{array}{r}0.31 \\
(23.1)\end{array}$ & & 0.19 & 0.2014 \\
\hline
\end{tabular}

Notes: (1) Figures in parentheses represent the absolute value of the $t$-statistic.

(2) Results are based on eq. (11) of text; $Y_{p x}, Y_{p i}, Y$ represent permanent income (earnings function), permanent income (three year weighted average) and measured income 1970-71, respectively. 


\section{Summary and conclusions}

This paper has examined the effects of sources of income, and invesmunit opportunities, on the savings behavior of farm households in India. The sources (composition) of income effect on savings was critically examined by relating savings to the agricultural and non-agricultural componenis of income. It was observed that the propensity to save out of non-igricultural income was higher than the propensity to save out of agricultural income. This result is 'unexpected' if one presumes that agricultural incomes reflect 'entrepreneurial income', investment opportunities and 'control over assets". However, the permanent income hypothesis offers an alternative explanalion for the observed result-the MPS out of non-agricultural income is higher because this income has a larger transitory component. The longitudinal nature of the data was used to isolate the permanent and transitusy components of income variance for each source of income. The results consistently supported the 'variability' hypothesis i.e. MPS out of nonagricultural income was higher when its transitory component was larger.

In the second part of th: paper the theoretical relationship between savings and investment opportunities was discussed and it was established that savings rates could either increase or decrease with an increase in these opportunities. The result depended critically on the possibilitics avialible to the household for transactions in the capital market. Two polar cases were studied: (1) perfect capital market and (2) no capital market. Opposite effects of investment opportunities on savings are predicted for the two groups savings should decline for the former group and increase for the latter. The conditions necessary for a proper investment opportunities index was extensively discussed, and an index proposed and tested. The empirical results supported the theoretical predictions: investment opportunities increased savings, ceteris paribus, for the subsistence group of households (no capital market) and had a negative effect for the non-subsistence group (relaticly' perfect capital market).

\section{Appendix}

\section{Data}

The National Council for Applied Economic Research (NCAER) undertook a survey (known as the Additional Rural Income Survey (ARIS)) of 5,115 households in 1968-69 to gather data on the distribution of income, and the pattern of consumption, savings and investment of these houscholds. The sample was selected according to a multi-stage stratificd probahility design; higher income households were oversampled. The survey was repeated in $1969-70$ and $1970-71$ on the same households, and the final version of the data refers to core sample of 4,118 houscholds.

C 
For purposes of analysis only households that were cultivators for all three years of the survey were selected. A household was defined as a cultivator if it engaged in any kind of self-cultivation on owned or leased land that was greater than 0.05 acres for all the three years of the survey. (There were 2,952 cultivators in 1970-71; the requirement that households have been cultivators for all three years reduced the sample size to 2,532.) Further, households were selected on the basis of occupational structure (no transactions in the land market for any year of the survey) logical consistency (savings numerically less than income) and a (possible) lack of transcription measurement error (gross income greater than Rs 500, and a saving rate of -150 percent to 75 percent). These 'restrictions' reduce the sample size from 2,532 to 1,980 farm households.

\section{Definitions}

(a) Income $(Y)$ : The income of a household is defined as the total of the earnings of all the members of a household during a reference period. This income can be business income (farm or otherwise), wages, rents (land and house property), interest and dividends on financial investments and pensions and regular contributions.

(b) Agricultural'non-agricultural income $\left(Y_{n}^{*} Y_{0}^{\prime}\right)$ : Any income obtained from work on owned farm (crop income, rental of land and agricultural implements) is considered to be algricultural income, $Y_{a}$. All other income (self-employment non-farming income, salliries, wages etc.) is considered to be non-agricultural income, $Y_{0}$.

(c) Satings $S$ : The savings of a household is defined as the change in net worth and computed as the difference between the change in the value of assets and the change in liabilities. This figure is adjusted for capital transfers. In other words, houschold silvings, $S$ is defined to be:

$$
S=\mathrm{d} A-\mathrm{d} L-\mathrm{d} K .
$$

where:

$$
\begin{aligned}
& \mathrm{d} A=\text { Gross change in the value of physical and financial assets, } \\
& \mathrm{d} L=\text { Net change in liabilities. } \\
& \mathrm{d} K=\text { Net inflow of cupital transfers. }
\end{aligned}
$$

The savings estimate includes via $\mathrm{d} A$ any purchase of consumer durables, and non-monetized investment that is undertaken by the household. Savings in the form of currency or gold and silver are not included due to lack of reliable data: nor has any adjustment been made for capital gains or losses incurred by the household. Depreciation on assets is also ignored. 


\section{References}

Adams, Dale W., 1973, The case for voluntary savings mobilization: Why rural capital markets flounder, Spring Review 19, June.

Bhalla, Surjit S., 1976a, Aspects of savings behavior in rural India, Studies in Domestic Fin.mie 31, World Bank.

Bhalla, Surjit S., 1976b, Measurement errors and the permanent income hypotheses Evidence from rural India, American Economic Review, forthcoming.

Fisher, Irving, 1930, The theory of interest (Macmillan Publishing Co.).

Friedman, Milton, 1957, A theory of the consumption function, National Bureau of Fonnimic Research (Princeton).

Hirshleifer, Jack, 1958, On the theory of optimal investment decisions, Journal of Political Economy, Aug.

Hirshleifer, Jack, 1970, Investment, interest and capital (Prentice Hall).

Holbrook, Robert, 1967, The three year horizon: An analysis of the evidence, Journal of Political Economy, Oct.

Holbrook, R. and F. Stafford, 1971, The propensity to consume separate types of income: A generalized permanent income hypothesis, Econometrica, Jan.

Houthakker, H.S., 1965, On some determinants of savings in developed and underdeveloped countries, in: E.A.G. Robinson, ed., Problems in economic development (London).

Kaldor, Nicholas, 1955 -56, Alternative thcories of distribution, Review of Economic Studies 23. 83-100.

Kelly, Allen E. and Jeffrey Williamson, 1968, Household saving behavior in the developing economies, Economic Development and Cultural Change, April.

Lewis, W.A., 1954, Economic development with unlimited supplies of l:1hor, Manchester Schoul of Economic and Social Studies, May.

Mayer, Thomas, 1972, Permanent income, wealth and consuniption (University of California Press).

McKinnon, Ronald I., 1973, Money $\therefore$ d capital in econumic development (Brookings Institution).

Mizoguchi, T., 1970, Personal savings \& consumption in post-war Japan (Tokyo).

Modigliani, Franco and R. Bruınberg, 1954, Utility analysis and the consumption function: An interpretation of cross-section data, in: R. Kurihara, ed., Post Keynesian economics.

Modigliani, Franco, R. Brumberg and A. Ando, 1963, Life cycle hyputhesis of savings: Aggregate implications and tests, American Economic Review, March.

Musgrove, P., 1974a, Determination and distribution of permanent household income in urban South America, unpublished Ph.D. disizrtation, M.I.T., June.

Musgrove, P., 1974b, Determinants of urban household consumption and savings in Latin America: A summary of evidence from the ECIEL survey, Bronkings Institution, Sept., mimeo.

National Council for Applied Economic Research, 1974, Credit requirements for agriculture (New Delhi).

National Council for Applied Economic Research, 1974. Additional rural incomes survey, Final Report (New Delhi).

Noda, T., 1970, Savings of farm households, in: K. Ohkawa et al, ed., Agricultural and economic growth: Japan's experience (Princeton Universtly Press).

Ong, Marcia L., D. Adams and I.J. Singh, 1976, Voluntary rural savings capacities in Taiwan 1960 1970. American Journal of Agricultural Economics, Aug.

Schultz, T., 1964, Transforming traditional agriculiure (Yale (Iniversily P'ress).

Shınohara, Miyohei, 1970. Structural changes in Japanese economic development, [xonomic Research Series 11, Hitotsuhushi University, Tokyo.

Taylor, Lester D, 1971, Saving out of different types of income, Browkings Papers on Economic Activities.

Weber, W.E., 1970, Effect of interest rates on aggregate consumption American Economic Review, Sept.

Wright, C., 1967, Some evidence on the interest elasticity of consumption, American Economic Review, Sept. 